\title{
Research of Flipped Classroom based on Students' Perceptions
}

\author{
İbrahim Yasar Kazu ${ }^{\rtimes}$ \\ Cemre Kurtoğlu ${ }^{2}$
}

'Firat University Education Faculty, Department of Education Science, Elazig, Turkey.

Email:ivkazu@firat.edu.trTel: +905303290996

${ }^{2}$ Ministry of Education, English Teacher Elazig, Turkey.

Email:cemrekurtoghu@hotmail.com Tel:+905310211036

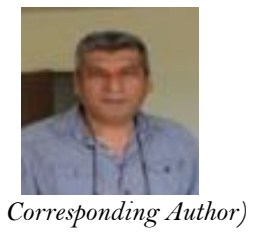

\begin{abstract}
Research of flipped classroom can be carried out in such dimensions as teacher, school manager, parents and students. This present research is aimed to investigate the secondary school students' flipped classroom readiness. The survey method was applied in this descriptive study. 'A Scale for Flipped Classroom Readiness of Secondary School Students' was applied as developed by Hao and adapted by Durak. The scale was applied to 383 th grade and 3628 th grade totally 745 students studying at five different secondary schools which were chosen randomly from city center of Elazig. Obtained data were analysed using SPSS Program Version 22.0. Their readiness for flipped classroom learning was investigated in five sub dimensions: 'self-directed learning, technology self-efficacy, in-class communication self-efficacy, motivation for learning and doing preview'. Their flipped classroom readiness was found positive in general. Students who have a computer and those who perceive themselves competent at using technological devices have more positive opinions on the flipped classroom.
\end{abstract}

Keywords: Doing preview, Educational technology, Flipped classroom, Motivation for learning, Self-directed learning, Technology selfefficacy.

Citation | İbrahim Yasar Kazu; Cemre Kurtoğlu (2020). Research of Flipped Classroom based on Students' Perceptions. Asian Journal of Education and Training, 6(3): 505-513.

History:

Received: 27 July 2020

Revised: 7 August 2020

Accepted: 12 August 2020

Published: 20 August 2020

Licensed: This work is licensed under a Creative Commons

Attribution 3.0 License $(\mathrm{oc})$ )

Publisher: Asian Online Journal Publishing Group
Acknowledgement: Both authors contributed to the conception and design of the study.

Funding: This study received no specific financial support

Competing Interests: The authors declare that they have no conflict of interests.

Transparency: The authors confirm that the manuscript is an honest, accurate, and transparent account of the study was reported; that no vital features of the study have been omitted; and that any discrepancies from the study as planned have been explained.

Ethical: This study follows all ethical practices during writing.

\section{Contents}

1. Introduction

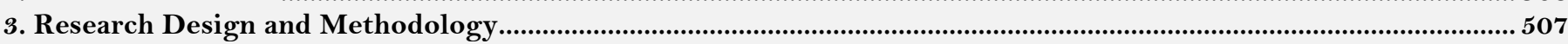

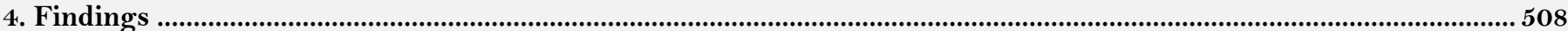

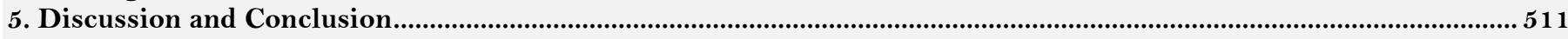

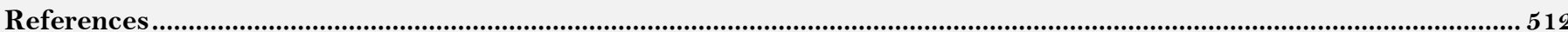




\section{Contribution of this paper to the literature}

Nowadays, our world is under the influence of a pandemic, Covid-19 virus. In order to reduce the spread of the Covid-19 virus, the widespread closures of schools become inevitable. Technology plays an important role in the continuation of education during an epidemic. This research was carried out to investigate students' readiness of flipped classroom, one of the technology based models. It is estimated to be useful for future studies.

\section{Introduction}

Recent developments in information and communications technology continue to impact every aspect of society, along with significant implications for the field of education. New technologies are being readily applied to design and facilitate the educational activities required in today's student- centered learning environments (Rafiola, Setyosari, Radjah, \& Ramli, 2020).

Especially, nowadays our world is under the influence of an epidemic, Covid-19. The coronavirus disease (COVID-19) causes closure of schools; beside that, face to face education has been interrupted and distance learning through computer and internet has become popular. Personal computing and communications devices have become important tools for learning and information transfer, and are thought as welcome additions to the learning environment. That's why, benefiting from information and communication technologies in education has become inevitable. In this way, the teaching and learning process can become more efficient and qualified individuals may be raised. Improvements in internet accessibility and speed have extended the global reach of education on an unprecedented scale across all levels from pre-school to post graduate studies. Learners with hand held devices and 24/7 internet access are no longer constrained to school hours. Indeed, such students are able to reach the information they need wherever and whenever they want. However, the many benefits of such advances have been seen to be slowed by the teaching profession itself. With the onset of constructivism in education in 2005, it was argued that certain traditional aspects should be retained to enable a 'behaviourist approach' (Anilan, 2014; Güven, 2010). Today we know that teachers' attitude and practices which limit the use of technology in the classroom can impede student- centered learning (Bolat, 2016). Efforts to counter these obstacles have in turn led to the popularization of radical concepts such as the flipped classroom (Filiz \& Kurt, 2015; Torun \& Dargut, 2015). The flipped classroom is centered on the idea that to attain success in education, the learning environment must be rearranged according to students' needs. Indeed, most education systems now emphasize student- centered learning, value individual differences, and call for the curriculum to be prepared accordingly. The main goal is to understand individuals' needs and to actively include them in all educational activities.

This flipped classroom research is based on investigating the flipped classroom readiness of secondary school students and determining whether they have necessary competences such as self- directed learning, technology self efficacy, in-class communication self-efficacy, motivation for learning and doing preview, or not. The researchers compared their readiness in terms of various variables (gender, grade, school where they study, having access to a computer, internet access, frequency of internet usage, the aim of using technological devices, how they perceive themselves using technological devices) across five sub-dimensions.

\section{Literature Review}

\subsection{What is a Flipped Classroom?}

21st century education systems emphasize the increasing importance of student-centred learning settings where students take part in tasks and direct their own learning (Hannafin, Hill, \& Land, 1997; Shea et al., 2012). In student-centered learning setting, students are required to participate in the learning actively. Student involvement needs to be organized through such educational activities as discussions, problem solving and peer learning (Zappe, Leicht, Messner, Litzinger, \& Lee, 2009). These activities are not straightforward and teachers can experience difficulties with time management and distributing the time devoted to lectures and active learning strategies evenly (Strayer, 2012). This kind of classroom, known also as 'inverted classroom' or 'reversed instruction', refers to a model that aims at coping with such challenges. Put forward by Bergmann and Sams (2012) flipped classroom was developed for those unable to take regular classes. This approach provides students with flexibility in their learning and thus they are given freedom to choose what they have learnt from a large number of resources and to direct their learning at their own pace. Students could watch video lectures before class and they were expected to prepare themselves accordingly. In this way what they were learning was reinforced with metacognitive activities such as group discussions, station technique, jigsaw, etc. during class (Bergmann, Overmyer, \& Wilie, 2012; Davies, Dean, \& Ball, 2013; Fulton, 2012; Hughes, 2012). As acquisition of subject knowledge is mainly undertaken out of class, flipped classroom allows teachers more time to apply active learning strategies. Moreover, this way of learning is regarded as beneficial for students since it allows them to learn at their own pace online. This approach provide students with a set of circumstances to turn into more active and interactive learners instead of passive listeners of the teachers and lectures (Mohanty \& Parida, 2016).

Flipped classroom comprises in-class learning and out of class learning activities as seen in Figure 1. Interactive group and individual based learning activities are done in class while out of class activities include computer based individual learning strategies (Bishop \& Verleger, 2013). In order to implement this model successfully, learners are expected to study the lecture through repetition. In this context, flipped classroom can be described as a learning process that is student centered, far from the traditional classroom understanding, based on active learning strategies, in which computer and internet software are used actively. 


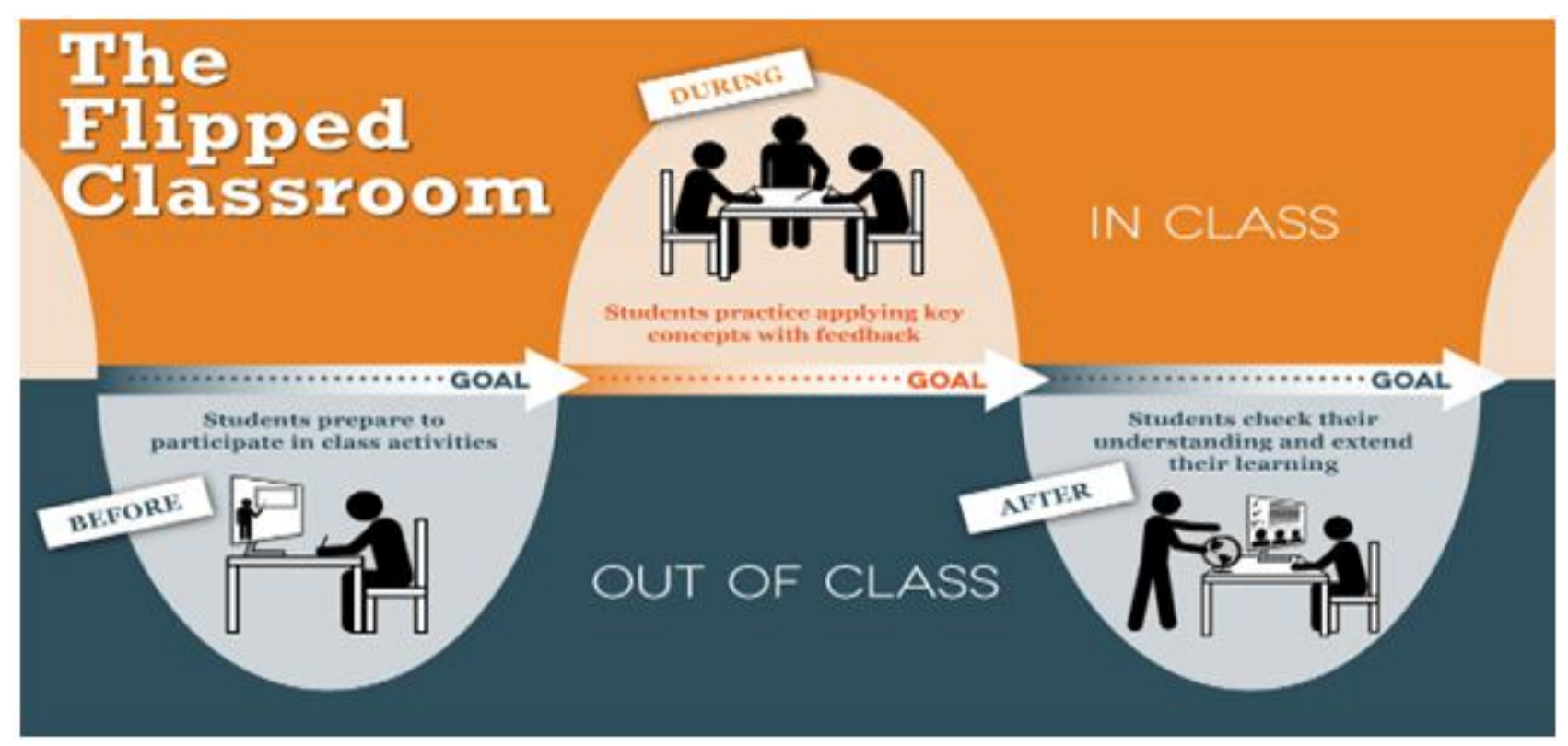

Source: (Faculty of Innovation Center, 2016)

Figure-1. Flipped classroom model.

\section{Research Design and Methodology}

\subsection{Research Model}

This study investigates the flipped classroom readiness of secondary school students. As it presents existing circumstances, a descriptive survey model is used to describe a previous or ongoing circumstance.

\subsection{Sample Group}

Table 1 summarizes demographic information about the students.

\begin{tabular}{|c|c|c|c|}
\hline Categories & Variables & Number of Respondents & Percentage \\
\hline \multirow[t]{2}{*}{ Gender } & Female & 396 & 53.2 \\
\hline & Male & 349 & 46.8 \\
\hline \multirow{5}{*}{ Secondary School } & Mustafa Kemal & 153 & 20.5 \\
\hline & Şehit Önder Pınar & 137 & 18.4 \\
\hline & Cumhuriyet & 187 & 25.1 \\
\hline & Bahçelievler & 171 & 23.0 \\
\hline & Avukat İbrahim Gök & 97 & 13.0 \\
\hline \multirow[t]{3}{*}{ Level } & $5^{\text {th }}$ grade & 383 & 51.4 \\
\hline & $8^{\text {th }}$ grade & 362 & 48.6 \\
\hline & Total & 745 & 100.0 \\
\hline
\end{tabular}

A total of 745 students from five different secondary schools in Elazig were enrolled in the study which was conducted in 2018-2019 academic year. $3835^{\text {th }}$ graders and $3628^{\text {th }}$ graders, totally 745 students, were recruited by simple random sampling in five schools.

\begin{tabular}{|c|c|c|c|}
\hline Categories & Variables & Number of Respondents & Percentage \\
\hline \multirow{2}{*}{ Do you have a computer? } & Yes & 423 & 56.8 \\
\hline & No & 322 & 43.2 \\
\hline \multirow{2}{*}{ Do you have an Internet access? } & Yes & 478 & 64.2 \\
\hline & No & 267 & 35.8 \\
\hline \multirow{4}{*}{ How often do you use the Internet in a day? } & Less than 1 hour & 356 & 47.8 \\
\hline & 1-3 hours & 297 & 39.9 \\
\hline & 4-6 hours & 55 & 7.4 \\
\hline & More than 6 hours & 37 & 5.0 \\
\hline \multirow{3}{*}{ Why do you use the Internet most? } & Social media & 186 & 25.0 \\
\hline & Entertainment & 341 & 45.8 \\
\hline & Study & 343 & 53.0 \\
\hline \multirow{4}{*}{$\begin{array}{l}\text { How do you perceive yourself to use the } \\
\text { technological devices? }\end{array}$} & Enough & 387 & 51.9 \\
\hline & Middle & 291 & 39.1 \\
\hline & Insufficient & 67 & 9.0 \\
\hline & Total & 745 & 100.0 \\
\hline
\end{tabular}




\subsubsection{Students' Technology Usage}

In this section, information about students' technology usage is explained. As shown in the Table 2, 56.8\% of the participants have access to a computer and $64.2 \%$ of them have internet access. In addition, $47.8 \%$ of them use the internet less than one hour, $39.9 \%$ of them between $1-3$ hours, $7.4 \%$ of them between $4-6$ hours and $5.0 \%$ of them more than 6 hours in a day. $25.0 \%$ of the participants use the internet mostly for social media, $45.8 \%$ for entertainment (playing games, listening to music, etc.), 53.0\% for studying, $51.9 \%$ perceive themselves as having enough expertise to use technological devices, 39.1\% express themselves as middle while $9.0 \%$ express having insufficient expertise.

\subsection{Data Collection Tool}

A Scale for Flipped Classroom Readiness of Secondary School Students' developed by Hao (2016) and adapted to Turkish by Durak (2017) was used for data collection. The scale consists of a total of 26 items and 5 subdimensions, namely self- directed learning, technology self-efficacy, in-class communication self-efficacy, motivation for learning and doing preview. The scale is a 5-point Likert Scale graduated from strongly disagree (1) to strongly agree (5). Factor analysis has been performed and a Cronbach's Alpha Score of 0.864 obtained. Cronbach's Alpha Scores for the sub dimensions are 0.942, 0.956, 0.897, 0.820, 0.705 respectively.

\subsection{Data Analysis}

Data were analyzed using SPSS Program Version 22.0. In order to analyze demographic data, descriptive statistical methods such as percentage, arithmatic mean, and standard deviation were used. Moreover, to evaluate the data according to the variables, Shapiro Wilk test and Kolmogrov Smirnov were performed and homogeneity of variances tested. According to the results, since the distribution is not normal $(\mathrm{p}<0.05)$, Mann Whitney $\mathrm{U}$ test and Kruskal Wallis test were used. In addition, to determine which group causes difference, Post hoc tests were used.

\section{Findings}

Findings are given as to whether the sub-dimension scores of the students that took part in sample group differed significantly from defined variables. The findings obtained by research are presented in the tables below.

Table-3. Students' beliefs about their flipped classroom readiness.

\begin{tabular}{l|c|c|c}
\hline Sub dimensions & N & Mean & Sd \\
\hline Self-directed learning & 745 & 3.83 & .61366 \\
\hline Technology self-efficacy & 745 & 3.61 & .77348 \\
\hline In-class communication self-efficacy & 745 & 4.00 & .92367 \\
\hline Doing previews & 745 & 3.86 & .95866 \\
\hline Motivation for learning & 745 & 4.04 & .87489 \\
\hline Flipped classroom & 745 & 3.87 & .60237 \\
\hline
\end{tabular}

The results of the analysis confirm that students 'strongly agree' with having the qualities flipped classroom requires $(\mathrm{M}=3.86)$. In the light of the data, it can be said that students are highly skilled at five sub-dimensions. As shown in Table 3, students 'strongly agree' with having self-directed learning skill $(\mathrm{M}=3.83)$, technology selfefficacy $(\mathrm{M}=3.61)$, in-class communication self-efficacy $(\mathrm{M}=4.00)$, motivation for learning $(\mathrm{M}=4.04)$, doing previews $(\mathrm{M}=3.87)$. Accordingly, the flipped classroom readiness of secondary school students is positive in general.

MWU test results performed to determine whether sub-dimension scores show difference between genders show a statistical difference between the scores of self-directed learning, doing previews and motivation for learning in favour of females; and between the scores of technology self-efficacy in favour of males. Males were more confident of their technology self-efficacy than females, while greater motivation for learning was indicated by females. No statistical difference was been found between gender for flipped classroom readiness. It is understood that the variable of gender has no significant effect on flipped classroom readiness in general.

According to KWH test results indicate whether sub-dimension scores show difference between schools, a statistical difference was found between the scores for self-directed learning, doing previews and motivation for learning and flipped classroom in favour of students at Mustafa Kemal Secondary School and Bahçelievler Secondary School. Students at these schools indicated greater flipped classroom readiness in comparison to others. In terms of technology self-efficacy, students from Cumhuriyet Secondary School and Bahçelievler Secondary School obtained higher scores than the others.

MWU test results indicate whether sub-dimension scores show difference between student grade show that a statistical difference was found between the scores for self-directed learning, doing previews and flipped classroom in favour of 5 th grade students; while the scores for technology self-efficacy were in favour of 8 th grade students. In the light of these findings, it can be stated that younger students are at higher level of flipped classroom readiness in comparison to older students. Older students indicated they were capable of using technology efficiently at a higher level than did younger students. However, no statistical difference was found between grades for in-class communication self-efficacy and motivation for learning.

The results of MWU tests in Table 4 confirm a statistical difference between self-directed learning, technology self-efficacy and flipped classroom in favour of students having computer and internet access $(\mathrm{p}<0.05)$. In other words, the students with a computer and internet access have better flipped classroom readiness in comparison to those who did not. Flipped classroom is a model that includes in- class and out of class activities. While out of class activities are performed, computer and internet are used actively. 
Table-4. Students having computer and internet access.

\begin{tabular}{|c|c|c|c|c|c|c|c|c|c|c|c|}
\hline \multicolumn{2}{|l|}{ Having computer } & \multirow{2}{*}{$\frac{\mathbf{N}}{423}$} & \multirow{2}{*}{$\frac{\text { Mean }}{397.71}$} & \multirow{2}{*}{$\frac{\mathbf{U}}{57652.00}$} & \multirow{2}{*}{$\frac{\mathbf{p}}{.000}$} & \multicolumn{2}{|c|}{ Having Internet access } & \multirow{2}{*}{$\frac{\mathbf{N}}{478}$} & \multirow{2}{*}{$\frac{\text { Mean }}{377.45}$} & \multirow{2}{*}{$\frac{\mathbf{U}}{61684.50}$} & \multirow{2}{*}{$\frac{\mathbf{P}}{.449}$} \\
\hline Self-directed & Yes & & & & & Self-directed & Yes & & & & \\
\hline & $\mathrm{No}$ & 322 & 340.54 & & & & No & 267 & 365.03 & & \\
\hline \multirow{2}{*}{$\begin{array}{l}\text { Technology } \\
\text { efficacy }\end{array}$} & Yes & 423 & 420.97 & 47594.50 & .000 & \multirow{2}{*}{$\begin{array}{c}\text { Technology self- } \\
\text { efficacy }\end{array}$} & Yes & 478 & 410.93 & 45871.50 & .000 \\
\hline & No & 322 & 309.98 & & & & No & 267 & 305.09 & & \\
\hline \multirow{2}{*}{$\begin{array}{l}\text { In-class } \\
\text { communication self- } \\
\text { efficacy }\end{array}$} & Yes & 423 & 380.52 & 64922.50 & .271 & \multirow{2}{*}{$\begin{array}{c}\text { In-class } \\
\text { communication } \\
\text { self-efficacy }\end{array}$} & Yes & 478 & 370.78 & 62752.00 & .704 \\
\hline & $\mathrm{No}$ & 322 & 363.12 & & & & No & 267 & 376.97 & & \\
\hline \multirow[t]{2}{*}{ Doing previews } & Yes & 423 & 386.19 & 62522.00 & .051 & \multirow[t]{2}{*}{ Doing previews } & Yes & 478 & 383.92 & 58595.00 & .060 \\
\hline & No & 322 & 355.67 & & & & No & 267 & 353.46 & & \\
\hline \multirow{2}{*}{$\begin{array}{l}\text { Motivation } \\
\text { learning }\end{array}$} & Yes & 423 & 392.07 & 60034.50 & .005 & \multirow{2}{*}{$\begin{array}{l}\text { Motivation for } \\
\text { learning }\end{array}$} & Yes & 478 & 374.65 & 63025.50 & .777 \\
\hline & No & 322 & 347.94 & & & & No & 267 & 370.05 & & \\
\hline \multirow[t]{3}{*}{ Flipped Classroom } & Yes & 423 & 403.56 & 55175.50 & .000 & \multirow{3}{*}{$\begin{array}{c}\text { Flipped } \\
\text { Classroom }\end{array}$} & Yes & 478 & 386.39 & 57490.00 & .025 \\
\hline & No & 322 & 332.85 & & & & No & 267 & 349.03 & & \\
\hline & Total & 745 & & & & & Total & 745 & & & \\
\hline
\end{tabular}

Students are expected to watch online videos or study the subject by means of using the internet and a computer. Therefore, having a computer and internet access is an important factor that effects their flipped classroom readiness. Clearly it is not surprising therefore that students who are able to readily use a computer and the internet show greater flipped classroom readiness. Moreover, a significant difference exists between those students who are confident of their technology self-efficacy and have computer and internet access, and those that are less confident and do not have regular access to this technology. As expected, the results confirm that the more students use technological devices, the better they are at using them.

Table-5. Frequencies of students' internet usage.

\begin{tabular}{|c|c|c|c|c|c|c|c|}
\hline Sub dimensions & Internet usage frequenc & $\mathbf{N}$ & Mean & $\mathbf{X}^{2}$ & sd & $\mathbf{p}$ & Post-hoc LSD \\
\hline \multirow{4}{*}{ Self-directed learning } & a'Less than 1 hour & 356 & 391.43 & 23.890 & 3 & .000 & $a>c$ \\
\hline & ${ }^{b} 1-3$ hours & 297 & 377.62 & & & & $a>d$ \\
\hline & c4-6 hours & 55 & 332.86 & & & & \\
\hline & ${ }^{\mathrm{d}}$ More than 6 hours & 37 & 218.26 & & & & \\
\hline \multirow{4}{*}{ Technology self-efficacy } & aLess than 1 hour & 356 & 319.96 & 43.545 & 3 & .000 & $\mathrm{~b}>\mathrm{a}$ \\
\hline & ${ }^{b} 1-3$ hours & 297 & 415.06 & & & & $\mathrm{c}>\mathrm{a}$ \\
\hline & ${ }^{c} 4-6$ hours & 55 & 445.17 & & & & $d>a$ \\
\hline & ${ }^{\mathrm{d}}$ More than 6 hours & 37 & 438.41 & & & & \\
\hline \multirow{4}{*}{$\begin{array}{l}\text { In-class communication } \\
\text { self-efficacy }\end{array}$} & aLess than 1 hour & 356 & 390.31 & 9.909 & 3 & .019 & $a>d$ \\
\hline & b1-3 hours & 297 & 367.43 & & & & $b>d$ \\
\hline & c4-6 hours & 55 & 353.11 & & & & \\
\hline & ${ }^{\mathrm{d}}$ More than 6 hours & 37 & 280.74 & & & & \\
\hline \multirow{4}{*}{ Doing previews } & aLess than 1 hour & 356 & 380.82 & 30.216 & 3 & .000 & $a>d$ \\
\hline & ${ }^{\mathrm{b}} 1-3$ hours & 297 & 394.18 & & & & $\mathrm{~b}>\mathrm{d}$ \\
\hline & ${ }^{c} 4-6$ hours & 55 & 321.73 & & & & \\
\hline & ${ }^{\mathrm{d}}$ More than 6 hours & 37 & 203.95 & & & & \\
\hline \multirow{4}{*}{ Motivation for learning } & aLess than 1 hour & 356 & 386.22 & 21.447 & 3 & .000 & $a>d$ \\
\hline & ${ }^{\mathrm{b}} 1-3$ hours & 297 & 386.64 & & & & $\mathrm{~b}>\mathrm{d}$ \\
\hline & ${ }^{\text {c4-6 hours }}$ & 55 & 290.20 & & & & \\
\hline & ${ }^{\mathrm{d}}$ More than 6 hours & 37 & 259.43 & & & & \\
\hline \multirow{5}{*}{ Flipped Classroom } & aLess than 1 hour & 356 & 395.60 & 21.146 & 3 & .000 & $a>d$ \\
\hline & ${ }^{\mathrm{b}} 1-3$ hours & 297 & 375.29 & & & & $b>d$ \\
\hline & c4-6 hours & 55 & 330.53 & & & & \\
\hline & ${ }^{\mathrm{d}}$ More than 6 hours & 37 & 232.69 & & & & \\
\hline & Total & 745 & & & & & \\
\hline
\end{tabular}

When Table 5 is examined, it is clearly seen that a statistical difference has been found between the scores of self-directed learning in favour of those students who use the internet less than one hour in a day compared to students using it between 4-6 hours and more than 6 hours $(\mathrm{p}<0.05)$. In addition, students using the net 1-3 hours, 4-6 hours and more than 6 hours obtain higher scores on technology self-efficacy than students using the internet less. This result indicates that the more students use the internet, the more they perceive themselves to be proficient in using this technology. Moreover, a statistical difference was seen between the scores for in-class communication self-efficacy, doing previews, motivation for learning and flipped classroom in favour of students using the internet less than 1 hour and 1-3 hours rather than 4-6 hours and more than 6 hours. Based on this finding, it is possible to state that the less students use the internet, the more flipped classroom ready they are. 
Flipped classroom seeks to integrate technology into education. Students in a flipped classroom environment are also required to prepare for class and are likely to need to access information and watch lectures in their own time online using the internet. This study confirms that students who are currently using the internet less than 3 hours a day have more flipped classroom readiness.

Table-6. Learners using the internet for social media or entertainment.

\begin{tabular}{|c|c|c|c|c|c|c|c|c|c|c|c|}
\hline \multirow{3}{*}{$\begin{array}{l}\text { Using Internet fo } \\
\text { media }\end{array}$} & or social & \multirow{2}{*}{\begin{tabular}{|c|}
$\mathbf{N}$ \\
187 \\
\end{tabular}} & \multirow{2}{*}{$\begin{array}{r}\text { Mean } \\
322.84\end{array}$} & \multirow{2}{*}{\begin{tabular}{c|}
$\mathbf{U}$ \\
42657.50 \\
\end{tabular}} & \multirow{2}{*}{\begin{tabular}{|c|}
$\mathbf{p}$ \\
.000
\end{tabular}} & \multicolumn{2}{|c|}{$\begin{array}{c}\text { Using the internet for } \\
\text { entertainment }\end{array}$} & \multirow{2}{*}{\begin{tabular}{c|}
$\mathbf{N}$ \\
341 \\
\end{tabular}} & \multirow{2}{*}{$\begin{array}{c}\text { Mean } \\
347.93\end{array}$} & \multirow{2}{*}{$\begin{array}{c}\mathbf{U} \\
60331.50 \\
\end{array}$} & \multirow{2}{*}{$\frac{\mathbf{p}}{.003}$} \\
\hline & Yes & & & & & Self-directed & Yes & & & & \\
\hline & No & 558 & 389.05 & & & & $\mathrm{No}$ & 404 & 394.16 & & \\
\hline \multirow{2}{*}{$\begin{array}{l}\text { Technology } \\
\text { efficacy }\end{array}$} & Yes & 187 & 417.22 & 43921.00 & .002 & \multirow{2}{*}{$\begin{array}{c}\text { Technology self- } \\
\text { efficacy }\end{array}$} & Yes & 341 & 399.41 & 59684.00 & \\
\hline & No & 558 & 357.59 & & & & No & 404 & 350.71 & & .002 \\
\hline \multirow{2}{*}{$\begin{array}{l}\text { In-class } \\
\text { communication } \\
\text { efficacy }\end{array}$} & Yes & 187 & 354.80 & 48601.50 & .191 & \multirow{2}{*}{$\begin{array}{c}\text { In-class } \\
\text { communication } \\
\text { self-efficacy }\end{array}$} & Yes & 341 & 370.57 & 68053.00 & \\
\hline & No & 558 & 378.40 & & & & No & 404 & 375.05 & & .775 \\
\hline \multirow[t]{2}{*}{ Doing previews } & Yes & 187 & 339.33 & 45724.50 & .014 & \multirow[t]{2}{*}{ Doing previews } & Yes & 341 & 350.30 & 61141.00 & \\
\hline & No & 558 & 383.56 & & & & No & 404 & 392.16 & & .007 \\
\hline \multirow{2}{*}{$\begin{array}{l}\text { Motivation } \\
\text { learning }\end{array}$} & Yes & 187 & 350.91 & 47879.00 & .110 & \multirow{2}{*}{$\begin{array}{l}\text { Motivation for } \\
\text { learning }\end{array}$} & Yes & 341 & 363.57 & 65666.00 & .267 \\
\hline & No & 558 & 379.70 & & & & No & 404 & 380.96 & & \\
\hline \multirow[t]{3}{*}{ Flipped Classroom } & Yes & 187 & 348.22 & 47260.00 & .068 & \multirow{3}{*}{$\begin{array}{c}\text { Flipped } \\
\text { Classroom }\end{array}$} & Yes & 341 & 362.63 & 65420.00 & .237 \\
\hline & $\mathrm{No}$ & 558 & 380.59 & & & & No & 404 & 381.75 & & \\
\hline & Total & 745 & & & & & Total & 745 & & & \\
\hline
\end{tabular}

Table 6 shows that a statistical difference has been found between the scores for self-directed learning and doing previews in favour of those students who do not use the internet for social media and entertainment (such as playing games, listening to music, watching a movie, etc.). However, students who use the net for social media and entertainment indicated greater technology self-efficacy in comparison to the students who don't. In addition, no statistical difference was found between the scores for flipped classroom readiness and using the internet for social media and entertainment $(\mathrm{p}>0.05)$. In other words, using the internet for social media and entertainment has no effect on flipped classroom readiness.

Table-7. Learners using the internet for studying

\begin{tabular}{|c|c|c|c|c|c|}
\hline \multicolumn{2}{|l|}{ Using the internet for studying } & \multirow{2}{*}{$\frac{\mathbf{N}}{391}$} & \multirow{2}{*}{$\frac{\text { Mean }}{406.34}$} & \multirow{2}{*}{$\frac{\mathbf{U}}{56170.00}$} & \multirow{2}{*}{$\frac{\mathbf{p}}{.000}$} \\
\hline Self-directed learning & Yes & & & & \\
\hline & No & 354 & 336.17 & & \\
\hline \multirow[t]{2}{*}{ Technology self-efficacy } & Yes & 391 & 353.75 & 61924.50 & .013 \\
\hline & No & 354 & 394.26 & & \\
\hline \multirow[t]{2}{*}{ In-class communication self-efficacy } & Yes & 391 & 386.90 & 63772.00 & .062 \\
\hline & No & 354 & 357.65 & & \\
\hline \multirow[t]{2}{*}{ Doing previews } & Yes & 391 & 412.63 & 53713.00 & \\
\hline & No & 354 & 329.23 & & .000 \\
\hline \multirow[t]{2}{*}{ Motivation for learning } & Yes & 391 & 384.43 & 64738.00 & .123 \\
\hline & No & 354 & 360.38 & & \\
\hline \multirow[t]{3}{*}{ Flipped Classroom } & Yes & 391 & 398.82 & 5.903 .00 & .001 \\
\hline & No & 354 & 344.49 & & \\
\hline & Total & 745 & & & \\
\hline
\end{tabular}

The results of analysis shown in Table 7 reveal a statistical difference between the scores for self-directed learning, doing previews and flipped classroom in favour of those students who use the internet for studying $(p<0.05)$. Nevertheless, students who do not use the internet for studying are more confident of their technology self-efficacy in comparison to students who use it for studying. In light of this result, it is understood that students who use the internet for studying are at high level of flipped classroom readiness than those who don't. In order to implement flipped classroom successfully, students should be eager to study in their own time and to take charge of their own learning. They are required to watch lectures by means of online videos and such applications as Khan Academy, Moddle, Edpuzzle, etc. These findings confirm that usage of the internet for studying mostly effects students' flipped classroom readiness positively.

In Table 8, we see that a statistical difference exists between the scores of all sub-dimensions except in-class communication self-efficacy in favour of the students who perceive themselves ready enough to use technological devices in comparison to those who say their readiness is middle or insufficient $(p<0.05)$. When the nature of flipped classroom is taken into consideration, it is normal for students who are confident in their use of technological devices to have better flipped classroom readiness. Flipped classroom model implementation requires students to use technological devices actively. Students can now reach information and watch presentations whenever and wherever they want by means of tablet, smart phones, laptops, computers, etc. Therefore, being selfsufficient in using technological devices is of great importance for successful flipped classroom implementation. 
Table-8. Students' level of technological devices usage.

\begin{tabular}{|c|c|c|c|c|c|c|c|}
\hline \multicolumn{2}{|l|}{ Level of using technological devices } & \multirow{2}{*}{$\frac{\mathbf{N}}{387}$} & \multirow{2}{*}{$\frac{\text { Mean }}{381.74}$} & \multirow{2}{*}{$\frac{\mathbf{X}^{2}}{12.627}$} & \multirow{2}{*}{$\frac{\text { Sd }}{2}$} & \multirow{2}{*}{$\frac{\mathbf{p}}{.002}$} & \multirow{2}{*}{$\frac{\text { Post-hoc LSD }}{a>c}$} \\
\hline \multirow{3}{*}{ Self-directed learning } & ${ }^{a}$ Enough & & & & & & \\
\hline & ${ }^{\mathrm{b}}$ Middle & 291 & 381.85 & & & & $\mathrm{~b}>\mathrm{c}$ \\
\hline & cInsufficient & 67 & 284.06 & & & & \\
\hline \multirow{3}{*}{ Technology self-efficacy } & ${ }^{\mathrm{a} E n o u g h}$ & 387 & 415.31 & 39.770 & 2 & .000 & $\mathrm{a}>\mathrm{c}$ \\
\hline & ${ }^{\text {b} M i d d l e ~}$ & 291 & 342.79 & & & & $\mathrm{~b}>\mathrm{c}$ \\
\hline & 'Insufficient & 67 & 259.82 & & & & \\
\hline \multirow[t]{3}{*}{ In-class communication self-efficacy } & ${ }^{\mathrm{a} E n o u g h}$ & 387 & 380.17 & 2.006 & 2 & .367 & \\
\hline & bMiddle & 291 & 370.93 & & & & \\
\hline & cInsufficient & 67 & 340.57 & & & & \\
\hline \multirow{3}{*}{ Doing previews } & aEnough & 387 & 378.26 & 10.389 & 2 & .006 & $\mathrm{a}>\mathrm{c}$ \\
\hline & bMiddle & 291 & 384.22 & & & & $\mathrm{~b}>\mathrm{c}$ \\
\hline & cInsufficient & 67 & 293.90 & & & & \\
\hline \multirow{3}{*}{ Motivation for learning } & ${ }^{a}$ Enough & 387 & 381.58 & 7.170 & 2 & .028 & $\mathrm{a}>\mathrm{c}$ \\
\hline & ${ }^{\mathrm{b}}$ Middle & 291 & 376.80 & & & & $\mathrm{~b}>\mathrm{c}$ \\
\hline & cInsufficient & 67 & 306.96 & & & & \\
\hline \multirow{4}{*}{ Flipped Classroom } & ${ }^{\mathrm{a} E n o u g h}$ & 387 & 391.41 & 21.528 & 2 & .000 & $a>c$ \\
\hline & bMiddle & 291 & 374.73 & & & & $\mathrm{~b}>\mathrm{c}$ \\
\hline & cInsufficient & 67 & 259.18 & & & & $\mathrm{a}>\mathrm{c}$ \\
\hline & Total & 745 & & & & & \\
\hline
\end{tabular}

Being proficient in using new technology is an important factor that effects students' flipped classroom readiness. The findings of this study confirm that those students perceiving themselves as being proficient enough or middle in using technological devices have more flipped classroom readiness in comparison to those reporting themselves insufficiently able to use them.

\section{Discussion and Conclusion}

Coronavirus (COVID-19) infection reported by China in December 2019 turned into an epidemic in weeks, which takes hold of the whole world. In order to reduce the spread of the COVID-19 virus, the widespread closure of schools, colleges, universities, and other educational institutions in many countries become inevitable. In this regard, face to face education has been interrupted and distance learning via internet and computer has recently become popular all over the world. Flipped classroom is one of the newest approaches that gives opportunity for online education. The urgent need for research has therefore been occurred. That's why, investigating the students' readiness for this model has vital importance both for endurance of teaching and learning process and also economic welfare of the countries.

The findings of this study indicate that the majority of secondary school students have quite high flipped classroom readiness. When the findings are evaluated in terms of the sub-dimensions, it is apparent that participant students have high self-directed learning skill. One of the most important characteristics of flipped classroom is to provide a student centered learning environment (Flipped Learning Network (FLN), 2014; Hamdan, McKnight, McKnight, \& Arfstrom, 2013; McLaughlin et al., 2014). In order to achieve this model, students must be able to administer their own learning process. Besides, they should be skilled at reaching and analysing information that they need. Although teachers are responsible for planning part of the process, students have the major role. That's why, it is highly significant for students to develop self-directed learning skills if they are to apply flipped classroom successfully.

When the literature is reviewed, it is seen that some studies have investigated the effect of self-directed learning skills on the success of the learning process and concluded that it has positive effect on online learning process (Chou, 2012a, 2012b; Corbel, 2003; Lai, 2011). It is thought that if a student is able to direct their own learning process, they would have a quite high flipped classroom readiness. Nevertheless, some studies show that the flipped classroom environment effects students' self-directed skill positively (Rutkowski \& Moscinska, 2013) and that the flipped classroom environment increases students' ability to direct their learning process. Flipped classroom is a model that actively seeks to integrate technology into education. According to Kol (2012) an individual in the 21 st century should possess the following characteristics: benefitting from technology efficiently, enterprising, productive, innovator, conscious of responsibilities, self-realized and open to change. As previously mentioned, in flipped classroom, students are required to access to online video lectures and some applications such as Moddle, Khan Academy, Edpuzzle, etc. to learn the subject prior to class time. Similarly, Kim, Kim, Khera, and Getman (2014) emphasize the usage of technology-based materials by students to prepare for class. That's why, this model requires using technology actively at each step of the process.

In the light of findings of the present study, it can be stated that students have high technology self efficacy and this effects their flipped classroom readiness positively. The findings confirm that the participants also have inclass communication self-efficacy. In this respect, when similar studies in the literature regarding the effect of strong communication between teacher and students on flipped classroom success are examined Al-Harbi and Alshumaimeri (2016); Chen, Wang, and Chen (2014); Clark (2013); McLean, Attardi, Faden, and Goldszmidt (2016); Alsancak (2015) \& Turan (2015) it can be seen that strong communication between both teacher and students and students and students has a positive effect on flipped classroom success. Moreover, flipped classroom improves teacher-students and students-students relationships. Similarly, Iyitoğlu (2018) conducted a study and stated that flipped classroom strengthens the relationship between teacher and students and provides a flexible 
learning environment. A study carried out by Steen-Utheim and Foldnes (2018) stated that in flipped classroom, students feel themselves more valuable, take part in productive group activities, have a closer relationship with their teacher, and cooperate with their teacher and friends. In addition, Cibik (2017); Roach (2014); Wimpenny and Savin-Baden (2013) found in similar studies evidence supporting these findings. Pishghadam, Shayesteh, and Rahmani (2016) showed that to become successful, students' motivation has critical importance in terms of their learning strategies and identity development. As it is well known, active learning is one of the ways of increasing motivation (Day \& Foley, 2006).

In flipped classroom, the major responsibility of in-class and out of class time is given to students, not teachers. Bergmann and Sams (2012) clearly state that learners are responsible for watching online video lectures, asking questions, completing preparations and sharing; furthermore, teachers are charged with guiding and giving feedback when needed. Literature review confirms that the more students have motivation for learning, the more they have flipped classroom readiness. This study confirms that participant students have high motivation for learning, so that it is possible to say their readiness for flipped classroom is positive. This model obliges learners to do previews by giving them major responsibility for the learning process. Fulton (2012) indicates that students have to do required preparation well before coming to the classroom, similarly, Sever (2014) states that in flipped classroom, students should have foreknowledge prior to class time in order to increase success. Thus, students being ready for doing previews means that they have high flipped classroom readiness. In flipped classroom, technology is used actively, moreover, use of a computer and access to the internet are two main factors for success with this model. When the findings of the study are examined, it is seen that students who have computer and internet access have more flipped classroom readiness in comparison to ones who don't. Flipped classroom consists of in-class and out of class activities. Out of class activities are undertaken with the aid of a computer and the internet. Lessons can be recorded on video so that students can watch them after class (Missildine, Fountain, Summers, \& Gosselin, 2013; O'Flaherty \& Phillips, 2015). In addition, watching these videos on a computerised device positively effects their flipped classroom readiness.

This study concludes that students who perceive themselves proficient in the use of technological devices are more flipped classroom ready than their peers who think they only have middling proficiency or who define themselves being insufficiently proficient. Flipped classroom is described as a teaching process that is carried out at home and requires use of the internet, and that reinforces students' self-directed learning with such activities as debates, peer or group activities in class (Kara, 2015). In order for students to undertake previews, they must be able to make efficient use of technological devices and it is expected that students who are proficient in the use of technology are more flipped classroom ready. In the light of this study the following recommendations are offered:

- In order to achieve flipped classroom well, all students' should be able to study using a basic internet enabled computing device.

- Students who perceive themselves insufficient in using technology, should be assisted to acquire basic competence in using a computer and learning materials via the internet.

- In this study, data was collected by means of a scale, but further experimental studies can be carried out to determine other factors effecting flipped classroom readiness.

- This study considered the flipped classroom readiness of $5^{\text {th }}$ and $8^{\text {th }}$ grade students. New and original studies should be carried out with learners at other levels.

- This study only analysed the flipped classroom readiness of students. Future studies may examine the flipped classroom readiness of teachers.

\section{References}

Al-Harbi, S. S., \& Alshumaimeri, Y. A. (2016). The flipped classroom impact in grammar class on EFL Saudi secondary school students' performances and attitudes. English Language Teaching, 9(10), 60-80.

Alsancak, S. D. (2015). The effect of flipped classroom model on academic achievement, self-directed learning readiness and motivation. Unpublished Doctoral Dissertation. Ankara: Gazi University Graduate School of Educational Sciences.

Anilan, H. (2014). Evaluation of Turkish grammar instruction based on primary school teachers' opinions. Educational Sciences: Theory and Practice, 14(5), 1914-1924.

Bergmann, J., Overmyer, J., \& Wilie, B. (2012). The flipped class: Myths vs reality. The Daily Riff. Retrieved from http://www.thedailyriff.com/articles/the-flipped-class-conversation-689.php. [Accessed November 20, 2019].

Bergmann, J., \& Sams, A. (2012). Flip your classroom: Reach every student in every class every day: International Society for Technology in Education (pp. 120-190). Washington DC: International Society for Technology in Education.

Bishop, J., \& Verleger, M. A. (2013). The flipped classroom: A survey of the research. Paper presented at the ASEE Annual Conference Exposition, Atlanta, Georgia.

Bolat, Y. (2016). The flipped classes and education information network (EIN). Journal of Human Sciences, 13(2), 3373-3388.

Chen, Y., Wang, Y., \& Chen, N. S. (2014). Is FLIP enough? Or should we use the FLIPPED model instead? Computers Education, 79, 16-27.

Chou, P. (2012a). Effect of students' self-directed learning abilities on online learning outcomes: Two exploratory experiments in electronic engineering. International Journal of Humanities and Social Science, 2(6), 177-178.

Chou, P. (2012b). The relationship between engineering students' self-directed learning abilities and online learning performances: A pilot study. Contemporary Issues in Education Research, 5(1), 35-36.

Cibik, B. (2017). The effects of flipped classroom model on learner autonomy. Unpublished Master's Thesis. Muğla: Muğla Sıtkı Koçman University Department of Foreign Languages Teacher Education.

Clark, K. R. (2013). Examining the effects of the flipped model of instruction on student engagement and performance in the secondary mathematics classroom: An action research study. Unpublished Doctoral Dissertation. Capella University.

Corbel, J. R. (2003). Online technologies self-efficacy, self-directed learning readiness, and locus of control of learners in a graduate-level web-based distance education program. Doctoral Dissertation). The University of Houston, Houston, TX.

Davies, R. S., Dean, D. L., \& Ball, N. (2013). Flipping the classroom and instructional technology integration in a college-level information systems spreadsheet course. Education Technology Research Development, 61(4), 563-580.

Day, J. A., \& Foley, J. D. (2006). Evaluating a web lecture intervention in a human-computer interaction course. IEEE Transactions on Education, 49(4), 420-431. Available at: https://doi.org/10.1109/te.2006.879792.

Durak, H. Y. (2017). Turkish adaptation of the flipped learning readiness scale for middle school students. BartIn University Journal of Faculty of Education, 6(3), 1056-1068.

Faculty of Innovation Center. (2016). The University of Texas at Austin. Retrieved from https://facultyinnovate.utexas.edu/flippedclassroom. [Accessed February 10, 2020].

Filiz, O., \& Kurt, A. A. (2015). Flipped learning: Misunderstandings and the truth. Journal of Educational Sciences Research, 5(1), $215-229$. 
Flipped Learning Network (FLN). (2014). Definition of flipped learning. Retrieved from https://flippedlearning.org/definition-of-flippedlearning/. [Accessed November 5, 2018].

Fulton, K. (2012). Upside down and inside out: Flip your classroom to improve student learning. Learning \& Leading with Technology, 39(8), $12-17$.

Güven, S. (2010). The evaluation of primary education life sciences course books and workbooks according to the teachers' views. Education and Science, 35(156), 84-95.

Hamdan, N., McKnight, P., McKnight, K., \& Arfstrom, K. (2013). A review of flipped learning: Pearson's research and innovation network. Retrieved http://www.flippedlearning.org/cms/libo7/VA01923112/Centricity/Domain/41/LitReview_FlippedLearning.pdf December 26, 2019].

Hannafin, M. J., Hill, J. R., \& Land, S. M. (1997). Student-centered learning and interactive multimedia: Status, issues, and implication. Contemporary Education, 68(2), 94-97.

Hao, Y. (2016). Middle school students' flipped learning readiness in foreign language classrooms: Exploring its relationship with personal characteristics and individual circumstances. Computers in Human Behavior, 59, 295-303.

Hughes, H. (2012). Introduction to flipping the college classroom. Paper presented at the World Conference on Educational Multimedia, Hypermedia and Telecommunications.

Iyitoğlu, O. (2018). The impact of flipped classroom model on EFL learners' academic achievement, attitudes and self-efficacy beliefs: A mixed method study. Unpublished Doctoral Dissertation. İstanbul: Yıldız Teknik University, Institute of Social Sciences.

Kara, C. O. (2015). Flipped classroom. Bulletin of Thoracic Surgery, 9, 224-228.

Kim, M. K., Kim, S. M., Khera, O., \& Getman, J. (2014). The experience of three flipped classrooms in an urban university: An exploration of design principles. The Internet and Higher Education, 22, 37-50.

Kol, S. (2012). Development of attitude scale devoted to the usage of technology in pre-school education. Kastamonu Education Journal, 20(2), $543-554$.

Lai, H.-J. (2011). The influence of adult learners' self-directed learning readiness and network literacy on online learning effectiveness: A study of civil servants in Taiwan. Journal of Educational Technology \& Society, 14(2), 98-106.

McLaughlin, J. E., Roth, M. T., Glatt, D. M., Gharkholonarehe, N., Davidson, C. A., Griffin, L. M., \& Mumper, R. J. (2014). The flipped classroom: A course redesign to foster learning and engagement in a health professions school. Academic Medicine, 89(2), $236-243$. Available at: https://doi.org/10.1097/acm.0000000000000086.

McLean, S., Attardi, S., Faden, L., \& Goldszmidt, M. (2016). Flipped classrooms and student learning: Not just surface gains. Advances in Physiology Education, $40(1), 47-55$

Missildine, K., Fountain, R., Summers, L., \& Gosselin, K. (2013). Flipping the classroom to improve student performance and satisfaction. Journal of Nursing Education, 52(10), 597-599. Available at: https://doi.org/10.3928/01484834-20130919-03.

Mohanty, A., \& Parida, D. (2016). Exploring the efficacy \& suitability of flipped classroom instruction at school level in India: A pilot study. Creative Education, 7(5), 768-776. Available at: https://doi.org/10.4236/ce.2016.75079.

O'Flaherty, J., \& Phillips, C. (2015). The use of flipped classrooms in higher education: A scoping review. The Internet and Higher Education, 25, 85-95. Available at: https://doi.org/10.1016/j.iheduc.2015.02.002.

Pishghadam, R., Shayesteh, S., \& Rahmani, S. (2016). Contextualization-emotionalization interface: A case of teacher effectiveness. RIMCIS: International and Multidisciplinary Journal of Social Sciences, 5(2), 97-127. Available at: https://doi.org/10.17583/rimcis.2016.1907.

Rafiola, R., Setyosari, P., Radjah, C., \& Ramli, M. (2020). The effect of learning motivation, self-efficacy, and blended learning on students' achievement in the industrial revolution 4.0. International Journal of Emerging Technologies in Learning (IJET), 15(8), 71-82. Available at: http://dx.doi.org/10.3991/ijet.v15io8.12525.

Roach, T. (2014). Student perceptions toward flipped learning: New methods to increase interaction and active learning in economics. International Review of Economics Education, 17, 74-84. Available at: https://doi.org/10.1016/j.iree.2014.08.003.

Rutkowski, J., \& Moscinska, K. (2013). Self-directed learning and flip teaching: Electric circuit theory case study. Paper presented at the 41st SEFI Conference, Leuven, Belgium.

Sever, M. (2014). Turkish adaptation of the classroom engagement inventory. Education and Science, 39(176), 171-182.

Shea, P., Hayes, S., Smith, S. U., Vickers, J., Bidjerano, T., Pickett, A., \& Jian, S. (2012). Learning presence: Additional research on a new conceptual element within the Community of Inquiry (CoI) framework. The Internet and Higher Education, 15(2), 89-95. Available at: https://doi.org/10.1016/j.iheduc.2011.08.002.

Steen-Utheim, A. T., \& Foldnes, N. (2018). A qualitative investigation of student engagement in a flipped classroom. Teaching in Higher Education, 23(3), 307-324. Available at: https://doi.org/10.1080/13562517.2017.1379481.

Strayer, J. F. (2012). How learning in an inverted classroom influences cooperation, innovation and task orientation. Learning Environments Research, 15(2), 171-193. Available at: https://doi.org/10.1007/s10984-012-9108-4.

Torun, F., \& Dargut, T. (2015). A proposal for the applicability of flipped classroom model in mobile learning environments. Journal of Educational Sciences, 6(2), 20-29.

Turan, Z. (2015). The evaluation of flipped classroom method and examination of its effects on academic achievement, cognitive load and motivation. Unpublished Doctoral Dissertation. Erzurum: Atatürk University, Institute of Educational Sciences.

Wimpenny, K., \& Savin-Baden, M. (2013). Alienation, agency and authenticity: A synthesis of the literature on student engagement. Teaching in Higher Education, 18(3), 311-326. Available at: https://doi.org/10.1080/13562517.2012.725223.

Zappe, S., Leicht, R., Messner, J., Litzinger, T., \& Lee, H. (2009). Flipping the classroom to explore active learning in a large undergraduate course Paper presented at the Proceedings of the 2009 American Society for Engineering Education Annual Conference and Exhibition. 